\title{
Digital Pemasaran Pariwisata dan Pendekatan Soft Skill di Destinasi Wisata
}

\author{
Dame Afrina Sihombing ${ }^{1}$ dan Oda I. B. Hariyanto ${ }^{2}$ \\ ${ }^{1}$ Universitas Internasional Batam, dame@uib.ac.id \\ ${ }^{2}$ Universitas Internasional Batam, oda@uib.ac.id
}

\begin{abstract}
ABSTRAK
Pemasaran pariwisata dilakukan secara digital untuk menjangkau pasar yang luas, dalam rangka mempromosikan pariwisata ke dunia Internasional. Dalam dunia pariwisata adalah menumbuhkan kesadaran kemampuan soft skill, pembangunan kesadaran dan kemampuan soft skill terkesan terabaikan. Pembangunan kesadaran dan kemampuan soft skill tidak dapat dilakukan secara instan, tetapi harus secara bertahap sesuai dengan kemanpuan dan pemahaman, serta kondisi masyarakat di daerah destinasi tersebut. Kesadaran dan kemampuan soft skill masyarakat tentang moral etika dan tanggung jawab dalam menjalankan tugasnya menjadi hal utama. Rendahnya kesadaran dan kemampuan soft skill seperti moral etika terhadap tanggung profesional seringkali menjadi keluhan wisatawan yang berkunjung ke destinasi wisata. Akibat perlakuan seseorang yang tidak bertanggung jawab terhadap wisatawan dapat menimbulkan image negative. Hal tersebut akan menurunkan citra pariwisata secara nasional maupun di dunia internasional. Oleh sebab itu kemajuan teknologi penggunaan digital pemasaran pariwisata, harus berjalan simultan dengan pembangunan kesadaran dan kemampuan soft skill para pelaku usaha Industri pariwisata. Khususnya masyarakat di destinasi menjadi ujung tombak yang berada di garis depan dalam melayani secara langsung wisatawan yang berkunjung ke destinasi. Metode penelitian kualitatif dan pendekatan etnografi untuk menganalisis masalah, dengan alasan penelitian ini membahas tentang masalah aktual dan faktual terkinikan, dan untuk memahami perilaku sosial masyarakat setempat. Data yang dihasilkan berupa data deskriptif yang akan disusun secara sistimatis sebagai hasil penelitian.
\end{abstract}

Kata Kunci: Soft Skill, Digital Pemasaran Pariwisata

\begin{abstract}
Indonesia has abundant natural, cultural and human resources, along with development and developing tourism, simultaneously the government also launched destination branding. Tourism marketing is done digitally to reach a broad market, in order to promote tourism to the international world. The thing that is not less important in the world of tourism is fostering awareness of soft skills, building awareness and soft skill abilities seem neglected. Building awareness and soft skill abilities cannot be done instantly, but must be gradual in accordance with the ability and understanding, as well as the conditions of the community in the destination area. The awareness and ability of the community's soft skills about moral ethics and responsibility in carrying out their duties is the main thing. The low awareness and ability of soft skills such as moral ethics towards professional responsibility is often the complaint of tourists visiting tourist destinations. The result of treating someone who is not responsible for tourists can cause a negative image. This will reduce the image of tourism nationally and internationally. Therefore, the advancement of digital usage technology in tourism marketing must run simultaneously with the development of awareness and soft skills of tourism entrepreneurs. Especially people in the destination are at the forefront of being at the forefront of directly serving tourists visiting the destination. Qualitative research methods and ethnographic approaches to analyze problems, arguing that this study discusses updated actual and factual problems, and to understand the social behavior of local communities. The data generated in the form of descriptive data will be arranged systematically as a result of the research.
\end{abstract}

Keywords: Soft Skill, Digital Tourism Marketing

Diterima: 23 Januari 2019, Direvisi: 12 Maret 2019, Diterbitkan: 15 Agustus 2019 


\section{PENDAHULUAN}

Indonesia memiliki keindahan alam (natural resources) yang sangat luar biasa, setiap daerah memiliki karakteristik alam yang berbeda-beda. Karakteristik alam Indonesia ditentukan oleh geografis dan topografi dari masing-masing daerah, menampilkan keunikan dan ciri khas alam yang berbeda-beda pula. Demikian juga kekayaan budaya (cultural resources) yang mempesonakan dunia dari Sabang sampai Marauke, karena Indonesia terkenal sebagai negara yang multi etnis, serta sumber daya manusia (human Resources) yang berlimpah. Kondisi tersebut sebagai kekuatan dan daya tarik wisatawan mancanegara (wisman), maupun wistawan Nusantara (wisnu) dan terbuka peluang sebagai destinasi wisata Dunia. Negara Indonesia sangat menyadari kekuatan dan peluang yang dimiliki, oleh sebab itu sektor pariwisata menjadi salah satu sektor strategis dalam pembangunan nasional. Selama satu dekade terakhir ini, menunjukkan kontribusi yang signifikan dalam menopang perekonomian nasional, khususnya dalam memperoleh devisa negara (Dinas Pariwisata Daerah Istimewa Yogkarta, 2017). Dalam rangka meningkatkan kunjungan wisman dan wisnu maka pemerintah meluncurkan berbagai program dalam upaya mempercepat pembangunan dan pengembangan destinasi yang menjadi perioritas. Pemerintah pusat menfasilitasi untuk memperbaikan dan merenovasi beberapa destinasi utama yang sudah ada. Untuk itu Kementerian Pariwisata (Kemenpar) peluncurkan branding-branding destinasi untuk menyelaraskan dengan masterbrand (Wonderful Indonesia) untuk memperkuat positioning dari master-brand Wonderful Indonesia. Yuristiadhi et al. (2017) Branding merupakan salah satu hal terpenting dalam pemasaran produk wisata, termasuk di dalamnya destinasi wisata. Branding destinasi akan menciptakan sinergitas antara pusat dan daerah untuk mempromosikan pariwisata Indonesia tiap destinasi ke publik Internasional melalui digital pemasaran.

Indonesia mentargetkan kunjungan wisatawan di tahun 2020 adalah 20 juta kunjungan wisman ke Indonesia. Sedangkan Jepang sekarang ini telah tercapai 20 juta kunjungan wisman ke negara Jepang, Matsuyama the president of JNTO (2018), said "The number of international visitors to Japan reached 20 million in the middle of September 2017". Pada tahun 2020 memiliki target dua kali lipat dari sebelumya yaitu 40 juta wisman yang berkunjung ke Jepang. Untuk pemasaran Jepang sudah menggunakan digital pemasaran, JNTO (2016) "launched a digital marketing section as one of its efforts to reinforce digital marketing activities and ICT-based delivery of information". Digital pemasaran di nilai efisien karena memiliki jangkauan pasar yang luas keseluruh dunia, berdasarkan data dari world internet usage population statistic (2017) pengguna internet di seluruh dunia $54.4 \%$ dari total populasi 7643 billion. Sedangkan perkembangan digital di Indonesia lebih dari 50\% jumlah penduduk di Indonesia telah mengakses internet, $60 \%$ mengakses internet menggunakan ponsel pintar (smartphone). Demikian halnya sangat ironis, beberapa peristiwa yang memalukan terjadi di beberapa destinasi di Indonesia, dengan mudah juga akan tersebar luas melalui internet keseluruh dunia. Peristiwa tersebut akan mencoreng citra pariwisata Indonesia secara Nasional. Oleh sebab itu gencarnya pembangunan fisik pariwisata, dan promosi melalui digital, perlu diikuti dengan membangunan soft skill. Melakukan pendekatan kepada pelaku industry pariwisata khususnya masyarakat di daerah dengan membangun dan mengembangkan kemampuan soft skill; moral etika dan tanggung jawab professional. Merupakan hal yang bijak dan menjadi tanggung jawab bersama seluruh masyarakat, untuk menjaga citra pariwisata Indonesia di dunia internasional.

\section{KAJIAN PUSTAKA}

\section{Pemasaran Pariwisata di Era Digital}

Pemasaran pariwisata (travel market) melalui media digital sangat menguntungkan bagi promosi pariwisata Indonesia. Penyebaran informasi suatu objek dan destinasi wisata, akomodasi serta transportasi, memiliki jangkauan luas tanpa batas yang dapat diakses oleh wisman maupun wisnu. Penelitian Terina, Prabawa \& Manuputty, (2013) "pemasaran pariwisata menggunakan internet merupakan salah satu cara terbaik pada saat ini, karena penggunaan internet untuk pencarian informasi pariwisata sangatlah tinggi". Walaupun keberhasilan transaksi secara digital antara sellers dan buyers baru 30\%, selebihnya masih dilakukan dengan cara manual melalui Travel Mart dan Travel Fair. Tema Go Digital Be The Best Kementerian Pariwisata (Kemnpar) untuk mewujudkan Wonderful Indonesia merupakan strategi pemasaran untuk menyaingi Malaysia Truly Asia dan Amazing Thailand, dan mendekatkan diri kepada wisatawan sebagai konsumen. Ada tiga hal yang 
perlu diperhatikan untuk mendukung go digital dalam meningkatkan kunjungan wisman ke Indonesia. Melakukan (a) retaining your customers yaitu memberikan kesan pertama yang baik (the first impression), kepada wisman yang masuk ke Indonesia dengan mempercepat pelayanan di imigrasi. Suasana friendly dan helpful, serta tersedianya informasi kepariwisataan dengan jelas dan lengkap. (b) Ecquiring your customers yaitu sales strategic mengutamakan strategi Less for Less, seperti low cost carrier (LCC). (c) Winning the future customers yaitu menggunakan digital untuk memenangkan persaingan (Yahya, 2016).

Digital marketing pariwisata (DMP) melalui media digital memiliki mamfaat sebagai berikut: Pertama memperluas jangkauan promosi pariwisata dengan memiliki website maka produk pariwisata lebih bisa dikenal oleh wisnu maupun wisman. Kedua sebagai media, tanpa dibatasi oleh jangkuan area dan Waktu, promosi berlangsung selama 24 jam. Ketiga pengenalan perusahaan yang berkaitan dengan kepariwisataan lewat website. Keempat membangun kepercayaan terhadap perusahaan; hotel, travel agent, restoran, dan obyek wisata, akan lebih baik saat perusahaan tersebut mempunyai situs web resmi. Kelima, kini semua orang mencari informasi secara online karena lebih efisien dan efektif.

\section{Digital Saluran Promosi}

Saluran promosi pariwisata dapat dilakukan dengan dua cara yaitu Pertama, Above the line (ATL) dapat dilakukan dengan cara: (1) ATL offline melalui saluran; televise, radio, advertorial print, public space dan retail ambience, (2) ATL online melalui saluran; web banner, email, news letter, google, statistic web. Kedua, Below the line (BTL) dapat dilakukan dengan cara; (1) BTL off line melalui saluran; sales promotion, event, news publicity, sponsorship, social involvement, community involvement. (2) BTL online melalui saluran; sosial media, blog, online community, video sharing, online chatting (Helic Marketing Strategy, 2019). Online travel agents (OTAs) yang di kenal di Indonesia untuk pemesanan kamar hotel (reservation), dan biro perjalanan, tiket (travel agents) adalah sebagai berikut; Traveloka, booking.com, Agoda, expedia, pergipergi, tiket.com, hotelbeds, gta, HOSTELWOLRD, STAAH (Helic Digital Marketing, 2019). Strategi pemasaran yang dilakukan untuk mencapai target 20 juta wisman pada tahun 2020, ada tiga strategi pemasaran baru yang harus dilakukan yaitu Pertama menurunkan biaya konektivitas, strategi disebut hot deals artinya menurunkan biaya konektivitas saat pasar turun (low season). Kedua Competitive destination model (CDM) bersifat online, wisman diberikan info semaksimal mungkin tentang objek dan destinasi wisata di Indonesia. Informasi gambaran tentang keindahan alam dan keunikan budaya Indonesia, informasi tersebut dapat dicari dengan mudah melalui (search) baidu, media sosial IG dan FB. Ketiga, subsidi bagi wisman (incentive sales) yaitu bekerjasama maskapai penerbangan dengan beberapa wholesale atau agen luar negeri untuk membawa wisman ke Indonesia. Maskapai penerbangan yang bekerjasama dengan agen luar negeri akan diberi subsidi, besarnya subsidi bergantung pada jumlah wisman yang dibawa ke Indonesia dengan ketentuan tidak termasuk Jakarta dan Bali (Yahya, 2018).

\section{Perilaku Konsumen di Era Digital}

Ada tiga hal yang penting dalam aktivitas perekonomian yaitu produsen (pelaku usaha industry pariwisata, stakeholder), konsumen (wisnu dan wisman) dan distributor (agent atau perantara). Perilaku konsumen merupakan halhal yang mendasari konsumen untuk membuat keputusan pembelian. Oleh sebab itu perilaku konsumen menjadi perhatian secara khusus, ketika konsumen akan memutuskan untuk membeli suatu produk barang atau jasa, akan berpikir terlebih dahulu tentang harga, kualitas, fungsi atau kegunaan dari produk tersebut. Kegiatan memikirkan, mempertimbangkan, dan mempertanyakan produk sebelum membeli termasuk ke dalam perilaku konsumen.

Menurut Schiffman dan Kanuk. (2008) "Perilaku konsumen adalah suatu proses yang dilalui oleh seorang pembeli dalam mencari, membeli, menggunakan, mengevaluasi. Serta bertindak pada konsumsi produk dan jasa, maupun ide yang diharapkan dapat memenuhi kebutuhan seseorang tersebut". Keputusan membeli konsumen (wisatawan) dipengaruhi oleh dua faktor, yaitu faktor internal dan eksternal. Pertama faktor internal dipengarruhi oleh (a) motivasi sangat berpengaruh di dalam pertimbangan seseorang untuk memutuskan memilih, dalam berperilaku memberikan suatu dorongan untuk memenuhi kebutuhan dan keinginannya. (b) Keadaan ekonomi seseorang juga berpengaruh terhadap perilaku pengambilan keputusan dalam pembelian sebuah produk. (c) Sikap seseorang terhadap produk atau merek mempengaruhi 
tindakan membeli atau menggunakan produk tersebut. Kedua, faktor eksternal dipengaruhi oleh (a) Faktor budaya mempunyai pengaruh yang paling besar terhadap perilaku konsumen karena seseorang cenderung akan mengikuti budaya di daerah tempat tinggalnya. (b) Kelompok sosial dan kelompok referensi adalah ukuran yang dapat mempengaruhi pembentukan kepribadian dan perilaku. (c) Keluarga memiliki peranan dalam pembentukan sikap dan perilaku seseorang, terutama pada pembelian sebuah produk (Rahmani, 2018). (d) Pengetahuan; berkembangnya dan kemajuan teknologi informasi, konsumen sebelum memutuskan untuk memilih dan membeli dapat mencari informasi sebanyak mungkin melalui internet.

Mencari website yang berhubungan dengan produk yang diinginkan sehingga dapat melihat dan membandingkan produk satu dengan produk yang lain. Sekaligus dapat mengevaluasi komentar dari para penguna produk tersebut. Ada empat langkah yang dapat dilakukan oleh wisatawan sebelum melakukan perjalan ke destinasi wisata, mencari informasi sebanyak mungkin. Pertama mencari informasi melalui Kedua melakukan perbandingan antara satu dengan yang lain tentang hal pelayanan (content reviews \&cross service concierge) Ketiga melakukan analisa peninjauan pada media sosial (reviews social media). Keempat melakukan peninjauan isi dan komentar di media sosial (Content Ads social\& reviews) menganalisa melalui komentar tamu (Helic Digital Marketing. 2019). web site dan melakukan peninjauan (reviews).

\section{Kemampuan Soft Skill}

Pelaku usaha industri pariwisata dituntut mampu melakukan pencitraan terhadap situasi dan kondisi di destinasi dengan baik, termasuk didalamnya memberikan branding destinasi. Destination branding memiliki kekuatan untuk merubah presepsi dan cara pandang seseorang terhadap suatu tempat destinasi, termasuk melihat perbedaan destinasi dengan destinasi lainnya. Oleh sebab itu setiap orang wajib dan bertanggung jawab untuk menjaga nama baik destinasinya masing-masing, dan pada akhirnya akan tercipta suatu branding Indonesia sebagai destinasi wisata dunia. Pemasaran melalui digital memiliki efek penyebaran informasi dengan jangkauan luas tanpa batas yang dapat diakses oleh setiap orang tampa batas waktu, kapan dan dimana saja. Demikian halnya ketika terjadi peristiwa yang tidak menyenangkaan terhadap wisatawan maka dengan mudah akan tersebar luas keseluruh dunia. Hal tersebut akan membawa citra pariwisata Indonesia menjadi tidak baik. Kemampuan soft skills bagi pelaku usaha kepariwisataan harus menjadi syarat utama, terutama yang bertugas di garis depan (front of the line), bersentuhan langsung dengan wisatawan.

Soft skills merupakan kemampuan yang tidak terlihat (intangible) dari setiap orang, namun amat dibutuhkan sebagai bekal kesuksesan profesional pekerjaan. Menurut Hogan (1990) "Soft skills is a sociological term relating to a person's Emotional Intelligence". Kemampuan soft skills harus di rangsang secara terus menerus sehingga timbul menjadi suatu kesadaran dan

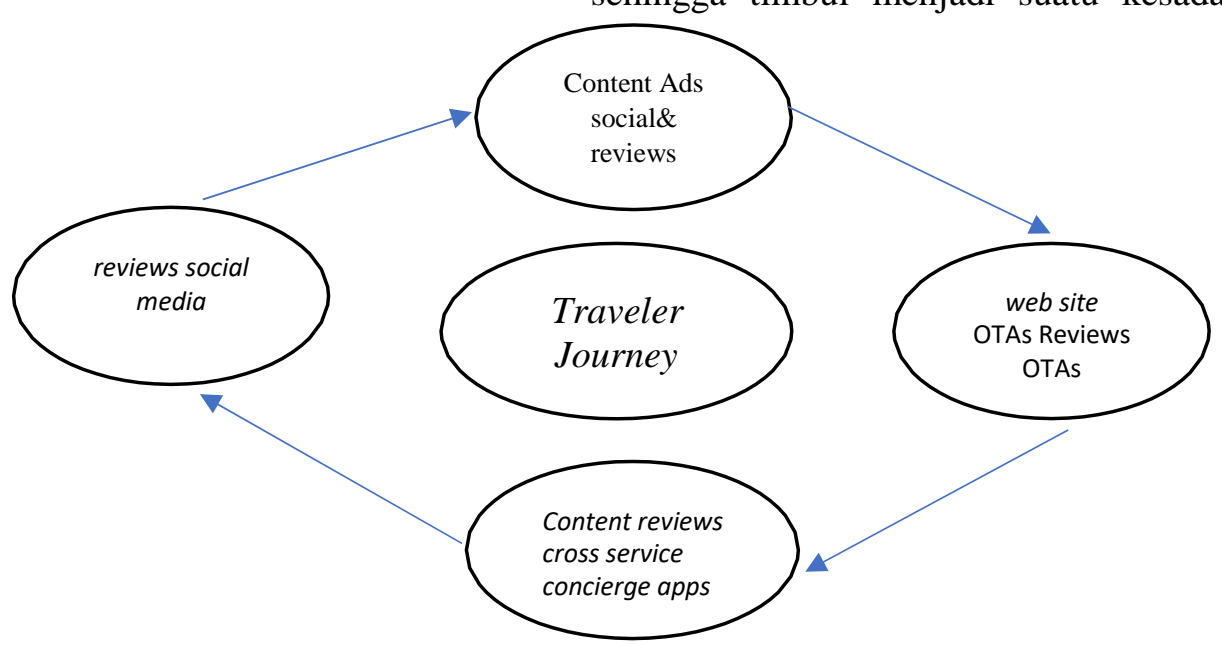

tanggung jawab seseorang terhadap tugasnya, Sumber: Modifikasi dari Helic Digital Marketing (2019)

Gambar 1. Travellers Booking Journey secara vertikal maupun horizontal (terhadap sesama, dan sebagai mahkluk ciptaan-Nya). Kemampuan soft skill menjadi kriteria yang dipersyaratkan agar sumber daya manusia lebih 
berkualitas, melakukan perubahan dan pembangunan soft skills tidak dapat dilakukan dalam waktu sekejap (instan). Kemampuan soft skills harus selalu dilakukan, dan diperbaharui sepanjang masa (long life education), menyangkut perilaku; tanggung jawab, ahlak dan moral individu.

\section{METODE PENELITIAN}

Metoda penelitian yang digunakan adalah metode penelitian kualitatif dengan alasan penelitian yang dilakukan dalam latar yang sesungguhnya atau alami, dan menghasilkan data deskriptif. Sedangkan Obyek penelitiannya merupakan studi kasus adalah peristiwa pelecehan terhadap wisatawan di Labuan Bajo. Teknik pengumpulan data melalui observasi, analisis dokumen secara off line maupun online, dan wawancara mendalam (indepth-interview), sebagai narasumber kunci (key informan) Teknik pemilih informan dilakukan dengan cara teknik bola salju (snowball sampling).

\section{HASIL DAN PEMBAHASAN \\ Kondisi Pariwisata di Indonesia}

Indonesia sedang membangun dan mengembangan fisik sarana dan prasarana pariwisata semaksimal mungkin hingga ke daerah-daerah. Mengfasilitasi perbaikan dan renovasi destinasi wisata yang telah ada, dalam upaya meningkatkan pembangunan ekonomi melalui sektor pariwisata. Bertujuan untuk pemerataan kesejahtaeraan masyarakat dengan mempeluas kesempatan bekerja, mengatasi penganguran, membuka kesempatan yang seluasluasnya usaha di bidang pariwisata dan pada akhirnya meningkatkan pendapatan perkapita. (Undang-Undang Republik Indonesia Tentang Kepariwisataan, 2009) Pariwisata memberikan kontribusi yang sangat besar terhadap devisa negara dan pendapatan asli daerah (PAD). Namun dalam isu-isu terkini menyatakan bahwa Indonesia tidak memberikan cukup penekanan pada keberlanjutan lingkungan hidup (mengakibatkan penggundulan hutang dan membahayakan spesies-spesies langka. Pengolahan air limbah (dengan cara daur ulang). kekuatiran-kekuatiran tentang keselamatan dan keamanan, terutama kerugian bisnis karena terorisme. Fenomena yang paling terasa dari perkembangan ICT (Information and Communication Technologie) maraknya penggunaan media sosial, memberikan dampak yang positif terhadap sektor pariwisata Indonesia, terutama dalam menyebarkan informasi terkait lokasi wisata dan layanan yang dapat dinikmati wisatawan di destinasi.

\section{Sumber Daya Manusia Pariwisata di Indonesia}

Pemerintah Indonesia melalui Kemenpar telah banyak melakukan upaya untuk meningkatkan kualitas sumber daya manusia ( SDM) diantaranya dengan memberikan Pelatihan Dasar SDM Pariwisata di Banyuwangi. Pelatihan dilakukan Dinas Pariwisata (Dispar) Provinsi Riau bekerjasama dengan Kementerian Pariwisata (Kemenpar), membekali pengetahuan pariwisata kepada 1.000 sumber daya manusia di Kepulauan Riau (CNN Indonesia, 2017). Ada tiga hal yang telah dilakukan untuk meningkatkan SDM yang berkualitas di bidang pariwisata. Pertama SDM pariwisata di Indonesia regional standar atau ASEAN MRA (mutual recognition arrangement), yaitu kompetensi setingkat ASEAN. Kedua pariwisata di Indonesai memiliki keunggulan $4 \mathrm{P}$ yaitu product, price, promotion dan place. Ketiga dalam pengembangan SDM pariwisata sudah menggunakan standar global agar dapat bersaing pada tingkat dunia.

Upaya untuk meningkatkan SDM pariwisata telah dilakukan semaksimal mungkin oleh pemerintah pusat (kemenpar) dan daerah (dinas pariwisata yang terkait), tiada lain dalam rangka meningkatkan kualitas pelayan, dan bersaing di pasar pariwisata global. Dalam rangka meningkatkan kunjungan wisatawan 20 juta di tahun 2020, maka Kemenpar telah meluncurkan 10 branding destinasi dengan skala perioritas. Artinya, 10 destinasi menjadi skala utama dalam pembangunan dan pengembangan meliputi 3A; (3 A: atraksi, amenitas dan aksesibiltas). Destinasi yang termasuk dalam skala periotas pembangunan dan pengembangan adalah Tanjung Kelayang, Tanjung Lesung, Mandalika, Morotai, Borobudur, Danau Toba, Kepulauan Seribu, Bromo Tengger Semeru, Wakatobi, dan Labuan Bajo. Pertanyaanya adalah sejauh mana pemerintah telah mempersiapkan SDM pariwisata dengan kemampuan soft skills yang handal. Penelitian di Harvard University menyimpulkan kesuksesan seseorang tidak ditentukan oleh pengetahuan keterampilan teknis saja (20\% oleh hard skills, sedangkan $80 \%$ oleh soft-skills (Neff dan Citrin. 2008).

Penelitian yang dilakukan oleh Mitsubishi Research Institute Jepang bahwa 
persentase terbesar yang memberi kontribusi keberhasilan dalam dunia kerja berturut turut ialah Soft Skill (40 \%), Networking (30\%), Keahlian bidang atau Hard skill (20\%) serta Finansial (10\%) (Wahyudiono, 2012) Suatu realita bahwa pendidikan di Indonesia lebih memberikan porsi yang lebih besar untuk muatan hard skill, bahkan bisa dikatakan lebih berorientasi pada pembelajaran hard skill saja.

\section{SIMPULAN DAN REKOMENDASI}

Berdasarkan hasil dan pembahasan penelitian di atas, dapat disimpulkan sebagai berikut yaitu bahwa pemasaran pariwisata melalui media digital sangat menguntungkan bagi promosi pariwisata Indonesia, penyebaran informasi objek dan destinasi wisata demikian cepat menyebar luas tampa batas ruang dan waktu. Dampak negatif adanya media digital, ketika wistawan merasa merasa tidak puas, dirugikan atau komplain, wisatawan dengan mudah menggunakan dengan media digital untuk menyampaikannya, sehingga dapat menyebar luas secara internasional. Kemampuan SDM pariwisata tidak terletak pada kemampuan hard skills saja tetapi lebih dominam pada kemampuan soft skills, karena pariwisata adalah hospitality, sehingga kesadaran dan kemampuan soft skills menjadi hal utama.

Diperioritaskan pembanguanan kesadaran dan kemampuan soft skills untuk 10 destinasi skala perioritas pengembangan, terutama untuk pelaku usaha industri pariwisata di pelosok-pelosok daerah terpencil. Diharapkan kompetensi soft skills menjadi syarat utama untuk pendampingi kompetensi hard skills, karena soft skills berkaitan dengan ahlak; etika, moral dan tanggung jawab secara profesional terhadap tugasnya dalam memberikan pelayanan prima (excellent service) kepada wistawan. Membuka peluang untuk penelitian lanjut fokus pada membangun kesadaran dan kemanpuan soft skills dengan pendekatan budaya, atau kearifan lokal budaya setempat.

\section{DAFTAR PUSTAKA}

Adiakurnia, Muhammad Irzal., ed. Sri Anindiati Nursastri. "3 Strategi Pemasaran Baru Pariwisata Indonesia hingga 2020".

Aprilyani, Jane., ed. Yudho Winarto. (2018). Kementerian Pariwisata bekali SDM pariwisata.

CNN Indonesia. (2017). Kemenpar Gelar Pelatihan Dasar SDM Pariwisata di

\section{Banyuwangi.}

Citrin., N. . (2008). BAB I. In Lesson from the top (pp. 2-57).

Dinas Pariwisata Daerah Istimewa Yogkarta. (2017). Strategi pemasaran pariwisata (pp. 1-156). Yoyakarta.

Duta Wisata. (2016). Sumber Daya Manusia Pariwisata Menggunakan Standard ASEAN MRA.

Hogan, Joyce., H. R. (1990). fak, 78758 (512).

Yuristiadhi, Ghifari., Sari, S. D. L. . (2017). Strategi Branding Pariwisata Indonesia Untuk Pemasaran Mancanegara. ETTISAL, 2(2), 31-39.

Matsuyama, Ryoichi. (2018). Japan National Tourism Organization (JNTO). Japan: Travel Voice Japanese Travel Trade News.

Matsuyama, Ryoichi. (2016). JNTO to add seven more overseas offices to bolster tourism boom. Japan: Kyodo news. April 2016.

Matsuyama, Ryoichi. 2016) Press Releases Japan National Tourism Organization Opens "Japan On-line Media Center". Agusus 2016

Rahmani, A. (2018). Faktor yang Memengaruhi Perilaku Konsumen dalam Mengambil Keputusan. Jurnal ISO/IEC 27001 Imformation Security Management.

Schiffman dan Kanuk. 2008. Perilaku konsumen Edisi 7. Jakarta: Indeks Undang-Undang Republik Indonesia Tentang Kepariwisataan, 2009)

\section{Biodata Penulis}

${ }^{1}$ Dame Afrina Sihombing dosen Program Studi Pariwisata Universitas Internasional Batam, mendapat gelar Magister Manajemen dari Universitas Internasional Batam. Saat ini memiliki ketertarikan penelitian pada bidang Manajemen dan Pariwisata.

${ }^{2}$ Oda I. B. Hariyanto sebagai dosen Program Studi Pariwisata Universitas Internasional Batam dan sebagai dosen tidak tetap pada Sekolah Tinggi Pariwisata Pelita Harapan. Mendapat gelar Doktor Ilmu Budaya dari Universitas Padjadjaran. Saat ini memiliki ketertarikan penelitian pada bidang Budaya, Pariwisata dan Makanan. 